\title{
Preliminary trophic analysis of leaf-mining Nepticulidae: pronounced feeding strategies in Middle and South America?
}

\author{
Andrius Remeikis ${ }^{2}$, \\ Arūnas Diškus ${ }^{1}$, \\ Jonas R. Stonis ${ }^{1^{*}}$ \\ ${ }^{1}$ Lithuanian University of Educational \\ Sciences and Baltic-American \\ Biotaxonomy Institute, Studentu St. 39, \\ Vilnius LT-08106, Lithuania \\ ${ }^{2}$ Institute of Ecology, Nature Research Centre, \\ Akademijos St. 2, Vilnius LT-08412, Lithuania
}

The paper briefly analyzes trophic relationships of Nepticulidae occurring in Middle and South America (the Neotropical and Ando-Patagonian regions) for the first time. The results show some peculiar features, including unexpectedly large percentage of taxa trophically associated with Asterales (Asteraceae) and Lamiales plants. However, because of insufficient sampling in most regions of the Caribbean and Middle and South America as well as the fact that only $50 \%$ of analyzed taxa are known in host-plant records, the results of current analysis should be treated as preliminary.

Keywords: Host-plants, Nepticulidae, trophic relationships

\section{INTRODUCTION}

The family was characterized with special reference to Middle and South America in monographic reviews by Puplesis, Robinson (2000) and Stonis et al. (2016b); however, very little information on host-plants and other particularities of the biology of Nepticulidae was provided.

Larvae of Nepticulidae (pygmy moths) are miners during all instars and feed inside leaves and occasionally other assimilation tissues of plants (Figs. 1-4, 8-10). One of the most pronounced and well-known trophic particularities is narrow diet breadth (stenophagy): most of Nepticulidae are either monophagous or strict oligophagous and rarely broad oligophagous, and only in a few known cases disjunct oligophagous (for the definition of the terms and the predominance of monophagy in Nepticulidae, see Diškus, Stonis, 2012 and Puplesis, Diškus, 2003). Though the presence of an ovipositor is not characteris-

\footnotetext{
*Corresponding author. E-mail: stonis@leu.lt
}

tic of most of Nepticulidae females, some species (e. g. Holarctic members of the Stigmella salicis group) are known to have a more or less protruding ovipositor. However, during our recent study of the high-Andean fauna, females with well-developed ovipositors were discovered (Figs. 5-7, 11-13). Seasonality of mining and adult activity have been insufficiently studied; we assume that the currently available data (Figs. 14, 15) provide evidence not so much about seasonality but rather about the time of collecting.

If we include all published species and all unpublished taxa available to us thanks to the study of ample material collected by us and collaborating colleagues during our ongoing project, the number of species of Nepticulidae fauna of the Caribbean and Middle and South America would reach 265 taxa (or about 234 identified species and 31 record based solely on host-plants and specific leafmines). About half of these taxa have host-plant data. Previously there were no attempts to analyze tropical relationships of Nepticulidae occurring in the Americas because of a dramatic lack of hostplant data. Now, having host-plant data for about 


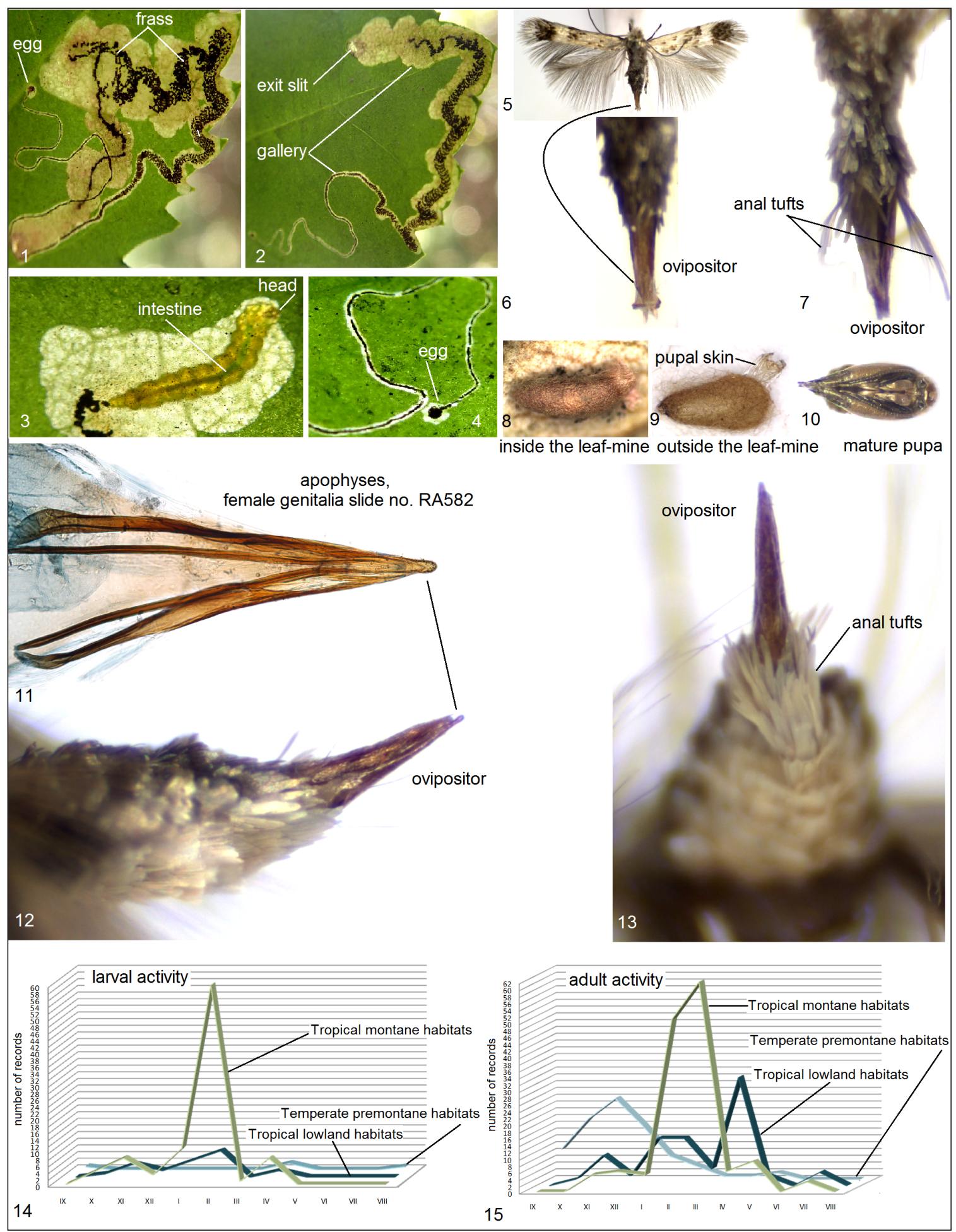

Figs. 1-15. Bionomics of Nepticulidae. 1-4 - documented leaf-mines of undescribed Stigmella species similar to S. rudis Puplesis \& Robinson, Chile, Metropolitana de Santiago, Rio Clarillo; 5, 6 - female of Stigmella sp., Peru, 35 km SE Huaraz, Cerro Cahuish, Quabrada Pucavado, 15-18.ii.1987, O. Karsholt (ZMUC); 7 - Stigmella sp., Peru, 32 km E Pacaran, 6-8.iii.1987, O. Karsholt (ZMUC); 8 - cocoon, Stigmella polylepiella, after Stonis et al., 2016c; 9 - same, S. sp.; 10 - pupa, after Stonis et al., 2016a; 11-13 - ovipositor of Nepticulidae female, Peru, 35 km SE Huaraz, Cerro Cahuish, Quabrada Pucavado, 15-18.ii. 1987, O. Karsholt (ZMUC); 14,15 - peaks of larval and adult activities 
$50 \%$ of species in average (or $36.6 \%$ for taxa occurring in temperate habitats and $53.6 \%$ for species occurring in predominantly tropical habitats), we can provide results of our preliminary trophic analysis of Nepticulidae of the Neotropical and Ando-Patagonian regions.

\section{MATERIALS AND METHODS}

Trophic analysis is based on host-plant records of 133 Caribbean and Middle and South American Nepticulidae taxa. It includes: (1) all species with host-plant records previously published by various authors including Puplesis and Robinson, 2000; Puplesis et al., 2002a, 2002b; van Nieukerken et al., 2016, etc. (it accounts for about $14 \%$ of the records used in the current analysis); (2) all species with hostplant records that we have published recently during our ongoing project; (3) all unpublished but identified species which became available to us after the recent study of sizeable Nepticulidae material from the Caribbean, and Middle and South America and which are described and prepared for publication; (4) all host-plant records of unidentified Nepticulidae taxa that we collected in South America thanks to various research projects together with scientific partners, including the initial project by $\mathrm{R}$. $\mathrm{Pu}$ plesis and S. R. Hill with Professor Giovanni Onore, the Pontifical Catholic University of Ecuador, Quito, Ecuador, in 1999. The latter portion of records represents about 31 undescribed Nepticulidae taxa, while all the remaining records used in the analysis represent 102 described species (or those species that are fully documented and prepared for description).

Most of the host-plant identifications were done by botanists, including Nixon Cumbicus Torres (Universidad Técnica Particular de Loja, Ecuador), Alvaro Pérez, Jaime Jaramillo, David Padilla (Pontifical Catholic University of Ecuador, Quito, Ecuador), Elfriede de Pöll (Universidad del Valle de Guatemala, Guatemala), and Caroline Whitefoord (Natural History Museum, London, United Kingdom), with consultations provided by many other plant specialists (see Acknowledgments). Trophic analysis was performed by doing a simple count of all available host-plant records and attributing them to phylogenetical lineages of plants. For this, an Angio- sperm phylogeny by a poster by Cole and Hilger (2016), a currently widely available and therefore probably the most popular phylogenetical scheme, was followed.

We follow Morrone (2015) in considering most of the Andes (including the equatorial high-Andes) as a South American transition zone belonging to the Ando-Patagonian Region (or the Andean region sensu Morrone, 2015).

Because of a preliminary character of the analysis and our effort for seeking simplicity, the enormous diversity of habitats were grouped down to a few ones: (1) páramo and puna, (2) tropical montane forests, including cloud forest habitats, (3) tropical lowland forests, including rainforest habitats and tropical coastal zone, and (4) temperate lowland and premontane forest habitats (the latter group was not presented together with other results because of insufficiency of data).

\section{RESULTS}

Preliminary analysis of tropical relationships of Nepticulidae occurring in the Caribbean and Middle and South America revealed a strong predominance of certain host-plants: most of the species are tropically associated with either Asterids (Asteridae, 41.5\%) or Rosids (Rosidae, $54.8 \%$ ); only a small fraction (3.7\%) is tropically associated with host-plants from other subclasses. Among the Asteridae-feeders, species tropically associated with Campanulids account for $57.1 \%$ and species feeding on Lamiids for $37.5 \%$; only a minor percentage (5.4\%) was detected as feeding on other Asterids. Among Rosidae-feeders, species tropically associated with Fabids account for $74.3 \%$ and species feeding on Malvids for $22.9 \%$; only a minor percentage $(2.8 \%)$ was detected as feeding on other Rosids.

In the fauna of the Neotropical region, hostplants from some families are very pronounced: feeding on Asteraceae plants was recorded for $23.7 \%$ of Nepticulidae taxa; on Rosaceae for 15.3\%; on Lamiaceae 12.7\%; on Fagaceae 8.5\%; on Euphorbiaceae 5.1\%; on Fabaceae and Malvaceae $4.2 \%$ (each); on Urticaceae $3.4 \%$; on Polygonaceae, Melostomataceae, and Ericaceae 2.5\% (each); and on Grossulariaceae, Salicaceae, Rhamnaceae, Myrtaceae, Scrophulariaceae, and Verbenaceae, $1.7 \%$ (each). Some Nepticulidae were also detected on Gunneraceae, 
Geraniaceae, Anacardiaceae, Meliaceae, Rubiaceae, and Boraginaceae ( $0.8 \%$ each).

In the fauna of the Ando-Patagonian region, host-plants from Asteraceae are the most pronounced too: Nepticulidae taxa with host-plant records on Asteraceae account for 33.3\%; there are also host-plants detected from Myrtaceae, Anacardiaceae, and Salicaceae and some Nepticulidae are expected to be miners of Nothofagaceae (see Stonis et al., 2015).

In total, 24 plant families and 16 plant orders (Fig. 16) are currently revealed as host-plant

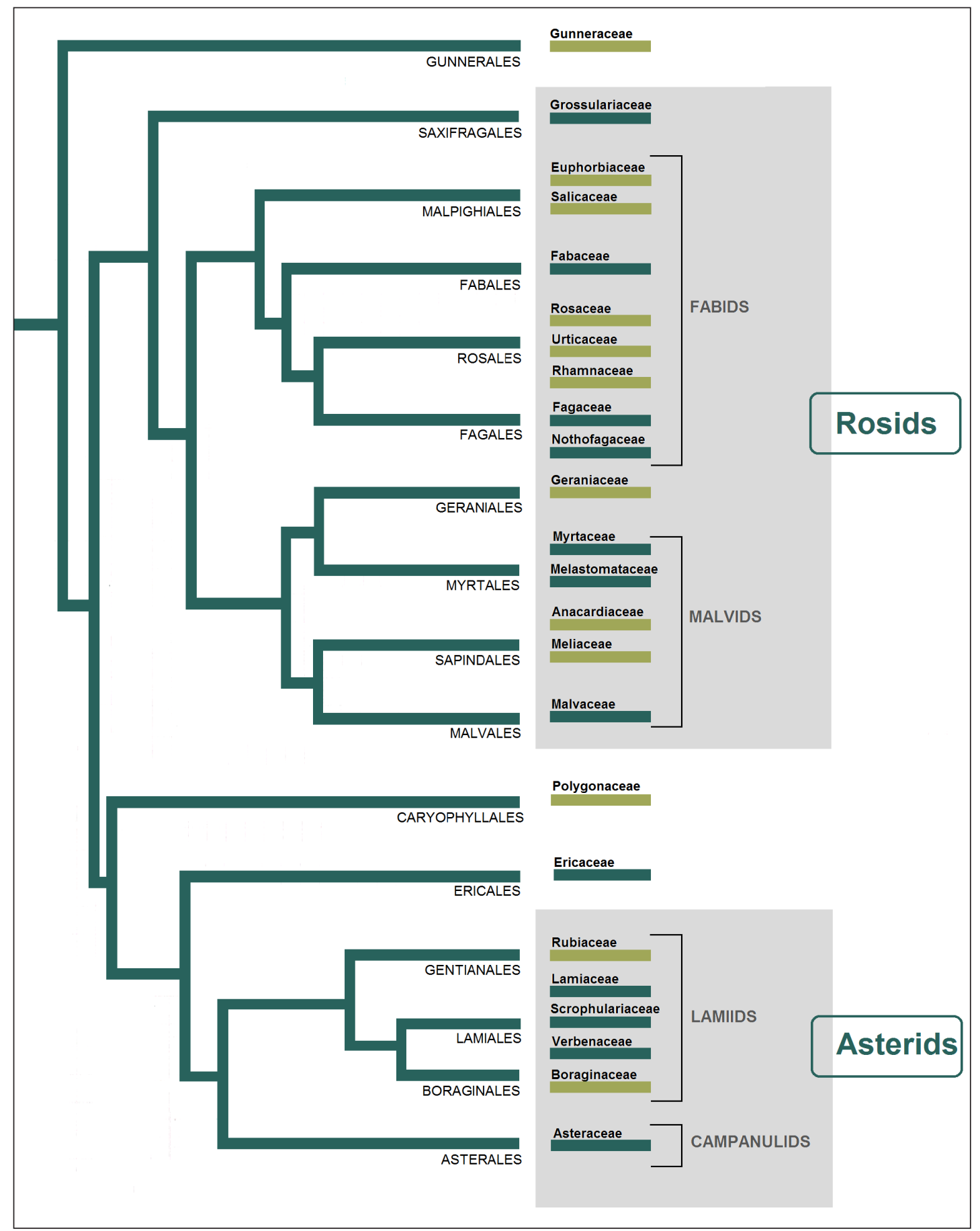

Fig. 16. The plant clades engaged by host-specific Nepticulidae occurring in America south of nonNeotropical Mexico (i. e., in the Neotropical and Ando-Patagonian regions) 
clades for the Nepticulidae occurring in America, south of Neartic Mexico.

Analysis of host-plant relationships according to the grouped habitats engaged by Nepticulidae (see Methods) indicates that páramo and puna can be characterized by a rather low generic diversity of host-plants, mostly belonging to the Asteraceae family (40.1\%) and much less to other families: Euphorbiaceae, Scrophulariaceae, Grossulariaceae, etc. (Figs. 17-19).

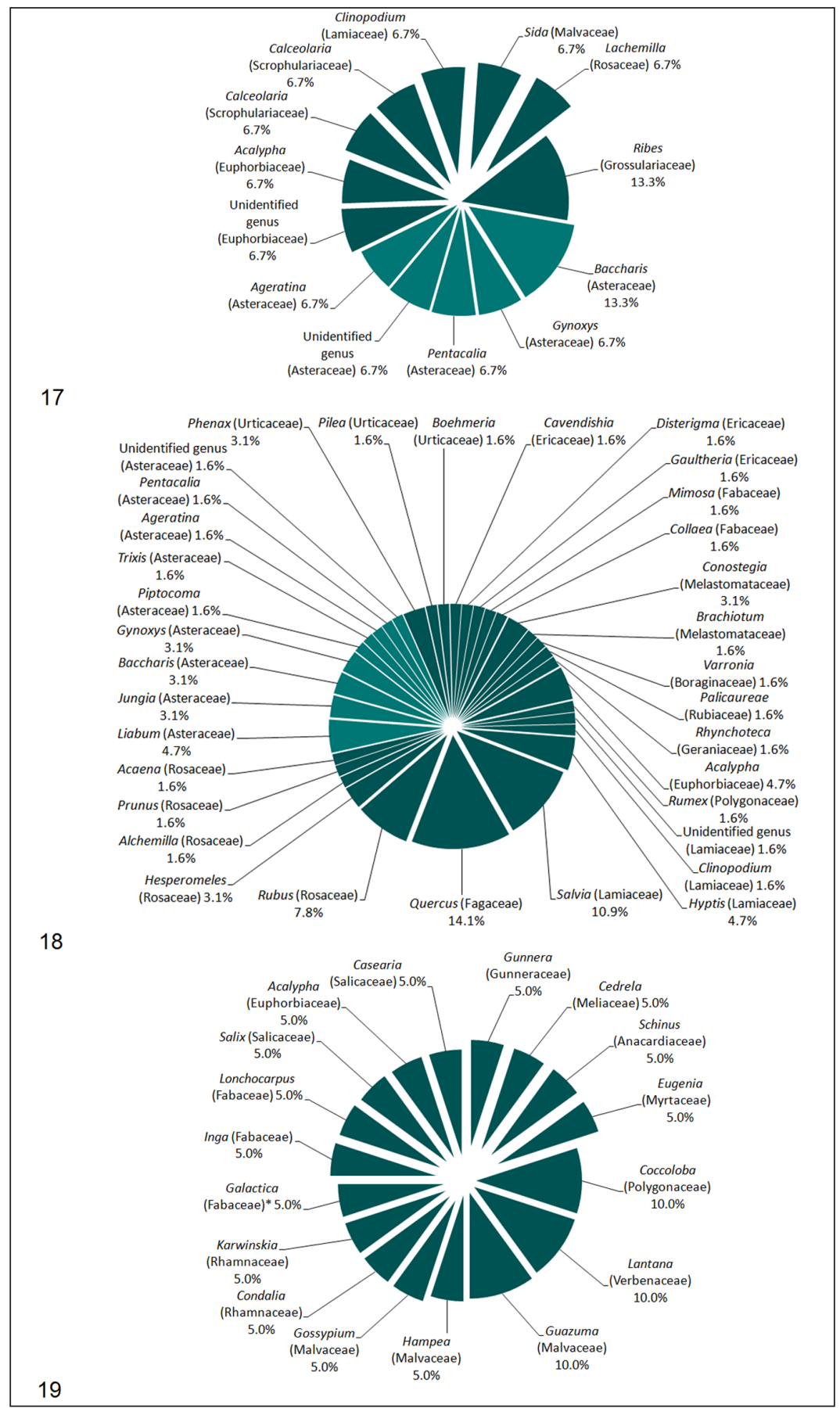

Figs. 17-19. Trophic relationships of Nepticulidae from different habitats. 17 - páramo and puna; 18 - tropical montane forests, including cloud forest habitats; 19 - tropical lowland forests, including rainforest habitats and tropical coastal zone 
On the other hand, tropical montane forests are characterized by the greatest generic diversity of host-plants, even more diverse than tropical lowland habitats. The high host-plant diversity in tropical montane forests is determined by a huge range of "smaller" habitats and sampling efforts, whereas the rather low hostplant diversity in tropical lowland habitats engaging vast territories is probably determined by fewer sampling efforts and by another, very important fact - Nepticulidae simply do not "like" the rainforest. Our recent observations in the Amazon rainforest of Colombia, Brazil and Peru in 2016 confirm that Nepticulidae are not common or abundant in the moist tropical lowland forest, i. e. the lower diversity is not an artefact.

\section{DISCUSSION}

Preliminary analysis showed some unexpected but pronounced feeding tendencies of Nepticulidae occurring in the Neotropics and the Ando-Patagonian region. In contrast to the Holarctic fauna, where only $0.2 \%$ of Nepticulidae species are associated with the Asterales order, in the region under study $24 \%$ of the species are Asterales-feeders (Fig. 20). A less pronounced

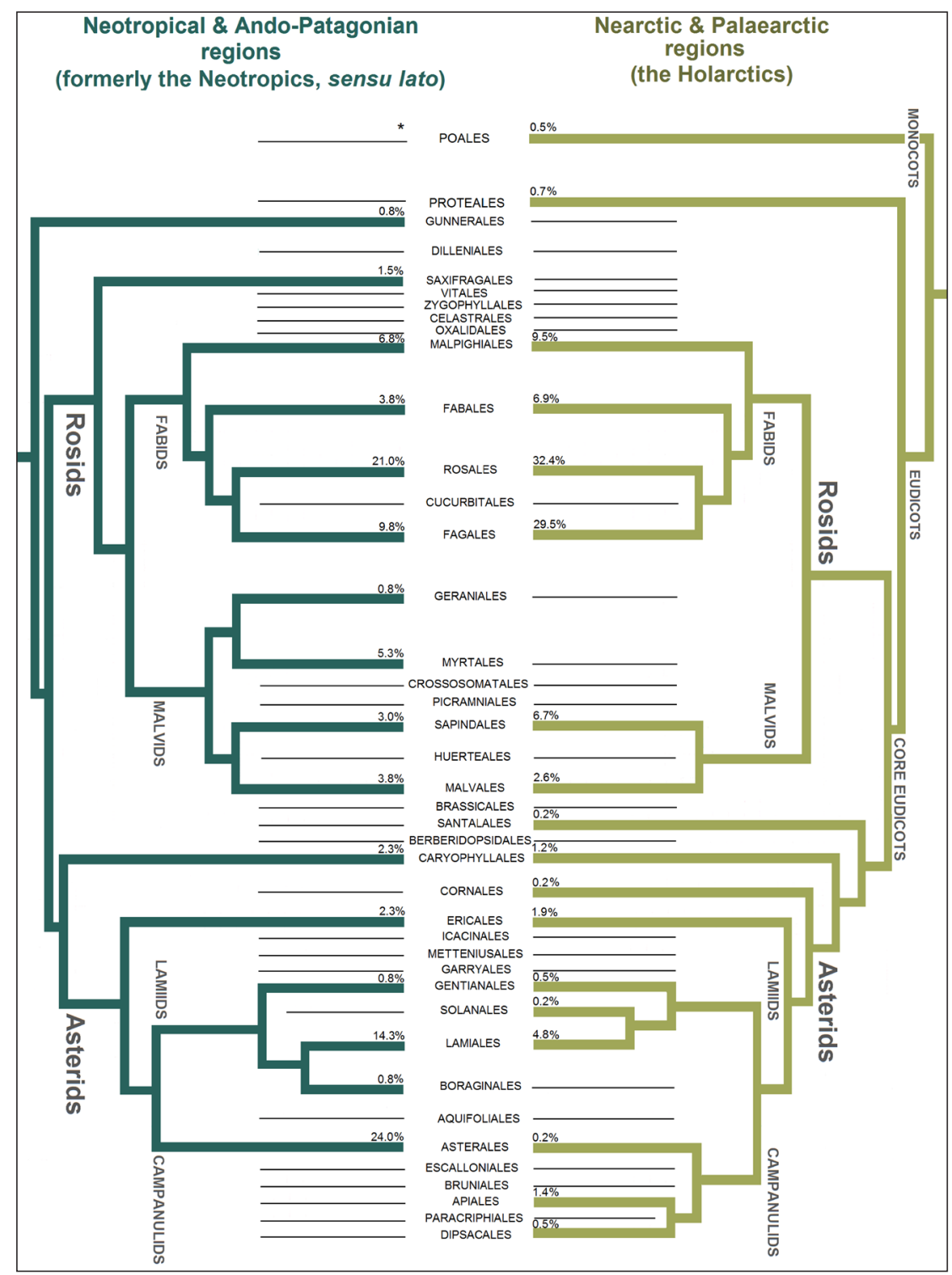

Fig. 20. The plant clades engaged by Nepticulidae in the Neotropical and Ando-Patagonian regions, and the Holarctics ${ }^{*}-$ see Discussion) 
but still striking difference between faunas of the Holarctic and Neotropical + Ando-Patagonian (formerly Neotropical, sensu lato) was detected among the Lamiales-feeders: they are very abundant (accounting for about $14.3 \%$ of all tropically investigated non-Nearctic American species). However, in contrast to the Holarctics, almost all of them belong to a single genus (Stigmella Schrank). On the other hand, the Rosales-feeders, the largest group of Nepticulidae in the Holarctics, are still less pronounced in non-Nearctic America (species on Rosales account for $21 \%$ in comparison with $32.4 \%$ in the Holarctics). Another interesting particularity of the American (Neotropical and Ando-Patagonian) fauna is the presence of leaf-miners on Myrtales, Geraniales, Boraginales (Fig. 20), and even on Poales (van Nieukerken, pers. comm.) which are still unknown in the Holarctic fauna with a history of about 250 years of study.

Though host-plant data were available only for half of the Neotropical and Ando-Patagonian taxa, our trophic analysis shows pronounced feeding strategies, though it has to be confirmed by further sampling.

\section{ACKNOWLEDGEMENTS}

We are indebted to Ole Karsholt (Zoological Museum, University of Copenhagen, Denmark) and Donald R. Davis (National Museum of Natural History, Smithsonian Institution, Washington, D. C., USA) for the loan of the Neotropical and Ando-Patagonian material. We thank botanists Nixon Cumbicus Torres (Universidad Técnica Particular de Loja, Ecuador), Alvaro Pérez, Jaime Jaramillo, David Padilla (Pontifical Catholic University of Ecuador, Quito, Ecuador), Elfriede de Pöll (Universidad del Valle de Guatemala, Guatemala), Caroline Whitefoord (Natural History Museum, London, United Kingdom) for the identification of numerous host-plant samples collected or photographed in Middle and South America. For helpful and frequent discussions on various host-plant plants we also thank: Arvind Singh (Banaras Hindu University, Varanasi, India), Narayanan Nair Mohanan (Jawaharlal Nehru Tropical Botanic Garden and Research Institute, India), José Luis Fernández-
Alonso (Universidad de Salamanca, Spain), Theodor C. H. Cole (Universität Heidelberg, Germany), Maximilian Weigend (University of Bonn, Germany), Franz Starlinger (Federal Research and Training Centre for Forests, Natural Hazards and Landscape, Vienna, Austria), and Alexandre Monro (Royal Botanic Gardens Kew, London, UK).

This study was supported by the Research Foundation of the Lithuanian University of Educational Sciences (2016). Andrius Remeikis is grateful for the research stipend received in 2016 from the Research Foundation of the Research Council of Lithuania.

Received 29 October 2016 Accepted 15 November 2016

\section{References}

1. Cole TCH, Hilberg HH. Institut für Biologie der Freien Universität Berlin, Systematische Botanik und Pflanzengeographie. Angiosperm phylogeny. Available at: http://www2. biologie.fu-berlin.de/sysbot/ (last viewed on 14 November 2016).

2. Diškus A, Stonis JR. [Leaf-mining insects of Lithuania. The Nepticulidae (Lepidoptera): taxonomy, chorological composition and trophic relationships]. Kaunas: Lututè Publishers; 2012. 220 p. Lithuanian.

3. Morrone JJ. Biogeographical regionalisation of the Andean region. Zootaxa. 2015; 3936(2): 207-36.

4. Puplesis R, Diškus A. The Nepticuloidea \& Tischerioidea (Lepidoptera) - a global review, with strategic regional revisions. Kaunas: Lutute Publishers; 2003. 512 p.

5. Puplesis R, Diškus A, Robinson GS. New Neotropical Nepticulidae (Lepidoptera) from the western Amazonian rainforest and the Andes of Ecuador. Bull Nat Hist Mus Entomol. 2002a; 71(1): 19-58.

6. Puplesis R., Diškus A., Robinson GS, Onore G. A review and checklist of the Neotropical Nepticulidae (Lepidoptera). Bulletin of the Natural History Museum, London (Entomology). 2002b; 71(1): 59-76. 
7. Puplesis R, Robinson GS. A review of the Central and South American Nepticulidae (Lepidoptera) with special reference to Belize. Bull Nat Hist Mus Entomol. 2000; 69(1): 3-114.

8. Stonis JR, Diškus A., Remeikis A., Davis DR, Solis MA, Cumbicus Torres N. The first record of Baccharis L. (Asteraceae) as a host-plant genus for Nepticulidae (Lepidoptera), with description of new Stigmella species from South America. Zootaxa. 2016a; 4136(1): 101-28.

9. Stonis JR, Diškus A, Remeikis A, Gerulaitis V, Karsholt O. Leaf-mining Nepticulidae (Lepidoptera) from record high altitudes: documenting an entire new fauna in the Andean páramo and puna. Zootaxa. 2016b; 00: 1-94.

10. Stonis JR, Diškus A, Remeikis A, Karsholt O. Do leaf-mining Nepticulidae occur in the natural but so threatened Andean Polylepis forests? Biologija. 2016c; 62(2): 83-97.

11. Stonis JR, Remeikis A, Davis DR. Ten new species from the Patagonian Andes (Argentina and Chile), mostly belonging to a newly designated Stigmella purpurimaculae group (Lepidoptera: Nepticulidae). Zootaxa. 2015; 3887(3): 321-53.

12. Van Nieukerken EJ, Doorenweerd C, Nishida K, Snyers C. New taxa, including three new genera show uniqueness of Neotropical Nepticulidae (Lepidoptera). ZooKeys. 2016; 628: 1-63.

\section{Andrius Remeikis, Arūnas Diškus, Jonas Rimantas Stonis}

\section{PRELIMINARI TROFINIŲ RYŠIŲ ANALIZĖ ATSKLEIDŽIA SAVITAS VIDURIO IR PIETŲ AMERIKOS NEPTICULIDAE (LEPIDOPTERA) MITYBOS TENDENCIJAS}

\section{Santrauka}

Preliminari trofinių ryšių analizè, apimanti visus 133 Nepticulidae taksonus, kurių mitybos augalai jau yra išaiškinti, atskleide kai kurias netikètas, bet ryškias neotropinio ir Andų bei Patagonijos regionų Nepticulidae mitybos specializacijos tendencijas. Skirtingai nei Holarkties faunoje, kur Asterales augalų minuotojai sudaro tik 0,2 \% žinomos faunos, mūsų tirtoje Amerikos faunoje 24 \% trofiškai ištirtų rūšių buvo išskirtinai Asterales augalų minuotojai. Ryškūs skirtumai nustatyti ir tarp Nepticulidae, susijusių su Lamiales augalais: Holarkties regione šios trofinès specializacijos rūšys sudaro 4,8\%, o neotropiniame ir Andų bei Patagonijos regionuose - 14,3\%. Skirtingai nei Holarkties fauna, Amerikos Lamiales minuotojų fauna nèra ịvairi taksonominiu požiūriu; beveik visos rūšys priklauso vienai genčiai (Stigmella Schrank). Rosales minuotojai, sudarantys didžiausią trofinę grupę Holarktyje (apie 32 \%), neotropinio ir Andų bei Patagonijos regionų faunoje sudaro $21 \%$. Iddomu tai, kad neotropinio ir Andų bei Patagonijos regionų Nepticulidae mitybos ryšiais yra susiję su Myrtales, Geraniales ir Boraginales augalais, šių ryšių iki šiol nenustatyta jau beveik 250 metų tyrinètoje Holarkties faunoje.

Raktažodžiai: mažieji gaubtagalviai, mitybiniai augalai, Nepticulidae, trofiniai ryšiai 